\title{
Distribusi Skabies pada Peternakan Sapi Potong di Kabupaten Barru Provinsi Sulawesi Selatan
}

\section{Distribution of Scabies in Beef Cattle in Barru District, South Sulawesi}

\author{
Meisi Nuriski ${ }^{1)}$, Ardilasunu Wicaksono ${ }^{2)}$, Chaerul Basri' ${ }^{2}{ }^{*}$ \\ ${ }^{1)}$ Fakultas Kedokteran Hewan, Institut Pertanian Bogor. \\ ${ }^{2)}$ Departemen Ilmu Penyakit Hewan dan Kesehatan Masyarakat Veteriner, Fakultas Kedokteran \\ Hewan, Institut Pertanian Bogor. \\ J1. Agatis Kampus IPB Dramaga, Bogor 16680, Jawa Barat. Indonesia
}

\author{
Article history \\ Received: Jun 7, 2019; \\ Accepted: Apr 7, 2020 \\ * Corresponding author: \\ E-mail: \\ chaerul@apps.ipb.ac.id \\ DOI: \\ 10.46549/jipvet.v10i2.97
}

\begin{abstract}
Beef cattle farms in Barru district are susceptible to various diseases, including scabies. The aim of this study was to analyze data about the distribution of disease temporally by measuring spreading speed, and spatially by mapping risk areas for scabies over the past three years. The data of this study was collected using the records from Dinas Peternakan and conducting interviews using structured questionnaires. This research was a descriptive study by measuring the incidence rate and describing the risk map using geographic information system (GIS). The results of this study indicated that, based on the incidence rate, the average of distribution rate of scabies in beef cattle in Barru is 13 cases per 10000 head-year. This incidence rate always increases every year. Furthermore, the highest incidence of disease occurred in Mallusetasi with incidence rate 35 cases per 10000 head-year. Three areas are classified as high risk, which were Mallusetasi, Tanete Riaja, and Barru. Control measures that have been carried out were not successful to reduce the spread of disease.
\end{abstract}

Keywords: Beef cattle; Distribution; Incidence rate; Risk; Scabies

\section{Abstrak}

Peternakan sapi potong di Kabupaten Barru rentan terhadap berbagai penyakit, termasuk skabies. Penelitian ini bertujuan menganalisis data distribusi kejadian penyakit secara temporal dengan mengukur kecepatan penyebaran, dan secara spasial dengan memetakan wilayah berisiko skabies selama tiga tahun terakhir. Data dalam penelitian ini menggunakan rekapan dari Dinas Peternakan dan wawancara mendalam menggunakan kuesioner terstruktur. Penelitian ini mengunakan metode deskriptif dengan mengukur incidence rate dan menggambarkan peta risiko menggunakan geographic information system (GIS). Hasil penelitian ini menunjukkan bahwa berdasarkan incidence rate, kecepatan rata-rata penyebaran skabies pada sapi potong di Kabupaten Barru sebesar 13 kasus per 10000 ekor-tahun. Nilai incidence rate tersebut selalu meningkat setiap tahunnya. Kejadian penyakit paling tinggi terjadi di kecamatan Mallusetasi dengan incidence rate sebesar 35 kasus per 10000 ekor-tahun. Terdapat 2 wilayah yang tergolong ke dalam risiko tinggi, yaitu Kecamatan Mallusetasi dan Kecamatan Tanete Riaja. Tindakan pengendalian yang telah dilakukan belum berhasil dalam mengurangi kecepatan penyebaran penyakit.

Kata kunci: Sapi potong; Penyebaran; Incidence rate; Risiko; Skabies 


\section{PENDAHULUAN}

Kebutuhan daging akhir-akhir ini terus meningkat, hal ini disebabkan oleh meningkatnya kesadaran masyarakat akan kebutuhan protein terutama protein hewani (FAO, 2010). Populasi ruminansia terutama sapi belum cukup dalam memenuhi kebutuhan daging skala nasional. Penurunan produktivitas menjadi penyebab jumlah populasi sapi tidak dapat memenuhi kebutuhan skala nasional (Ditjennak, 2014). Terdapat beberapa faktor yang dapat menurunkan produktivitas ternak, salah satunya penyakit parasitik. Skabies merupakan satu di antara penyakit parasitik yang sering dijumpai pada ternak di Indonesia dan cenderung sulit disembuhkan (Wardhana et al., 2006).

Skabies disebabkan oleh Sarcoptes scabiei, pada ternak lebih dikenal dengan sebutan kudis (Subronto, 2008). Ternak yang terserang penyakit ini akan mengalami penurunan berat badan, kualitas daging, dan kulit (April et al., 2006). Skabies endemis hampir di seluruh wilayah Indonesia. Sebanyak 2640 kasus skabies telah dilaporkan dan dijumpai menyerang berbagai jenis ternak di wilayah kerja Balai Penyidikan Penyakit Hewan Wilayah VI (Putra, 1994). Menurut Kementrian Pertanian (2014), pada keadaan kurang pakan, musim kemarau, dan lingkungan kandang kotor dapat mengakibatkan prevalensi skabies mencapai 4-11\%. Skabies juga termasuk ke dalam daftar zoonosis. Sebanyak 300 juta orang per tahun di dunia dilaporkan terserang skabies (WHO, 2014).

Dinas Peternakan Kabupaten Barru telah melakukan tindakan pengobatan dan monitoring secara rutin untuk mencegah penyebaran skabies. Kendala yang dihadapi dalam menanggulangi skabies adalah tidak ketatnya pengendalian lalu lintas sapi, serta sulitnya mengontrol sapi yang terkena skabies akibat sistem pemeliharaan secara ekstensif, sehingga pengendalian menjadi kurang efektif. Berdasarkan data yang diperoleh, kasus skabies masih sering terjadi di Kabupaten Barru selama tiga tahun terakhir. Oleh karena itu, diperlukan kajian terhadap data hasil monitoring skabies pada sapi potong di Kabupaten Barru.

Penelitian ini bertujuan menganalisis data distribusi kejadian penyakit secara temporal dengan mengukur kecepatan penyebaran, dan secara spasial dengan memetakan wilayah berisiko skabies selama tiga tahun terakhir di Kabupaten Barru Provinsi Sulawesi Selatan. Penelitian ini diharapkan mampu memberikan informasi yang dapat menjadi acuan bagi dinas dalam melakukan tindakan pencegahan dan pengendalian skabies di Kabupaten Barru.

\section{MATERI DAN METODE}

\section{WAKTU DAN TEMPAT PENELITAN}

Pengambilan data dilakukan pada bulan Agustus-September 2018 di Dinas Peternakan Kabupaten Barru. Pengolahan data dilakukan pada bulan Desember 2018-Januari 2019 di Laboratorium Epidemiologi, Divisi Kesehatan Masyarakat Veteriner dan Epidemiologi, Fakultas Kedokteran Hewan, Institut Pertanian Bogor.

\section{PENGOLAHAN DATA}

Data yang digunakan dalam penelitian ini berupa data primer dan data sekunder. Data primer merupakan data yang diperoleh langsung dari sumber asli dan tidak melalui media perantara (Nazir, 2003). Data primer dalam penelitian ini diperoleh melalui wawancara mendalam dengan petugas Dinas Peternakan Kabupaten Barru menggunakan kuesioner terstruktur. Data sekunder merupakan data yang diperoleh secara tidak langsung berupa bukti, catatan, atau laporan yang tersusun dalam arsip (Nazir, 2003). Data sekunder yang digunakan berasal dari rekapan hasil surveilans Dinas Peternakan Kabupaten Barru tahun 2015-2017.

Pengolahan data dilakukan dengan menghitung incidence rate menggunakan bantuan aplikasi Ms. Excel, dan menggambarkan peta risiko penyebaran menggunakan perangkat lunak berbasis geographic information system (GIS), yaitu software ArcGIS version 10.3. Selain itu, penelitian ini menggunakan kajian pustaka (literature survey) sebagai analisis deskriptif untuk menganalisis faktor-faktor yang memengaruhi kejadian skabies.

\section{INCIDENCE RATE}

Incidence rate atau laju kejadian adalah tolak ukur dari kecepatan rata-rata penyebaran penyakit. Insidensi menggambarkan jumlah kasus baru yang terjadi di dalam suatu populasi 
selama periode waktu tertentu. Menghitung angka incidence rate suatu penyakit, harus diketahui terlebih dahulu jumlah penderita baru dan jumlah yang mungkin terkena penyakit baru (population at risk) (Cameron, 1999). Berikut ini rumus untuk menghitung incidence rate:

$$
\text { Incidence rate }(I R)=\frac{\text { Jumlah kasus baru penyakit dalam kurun waktu tertentu }}{\text { Rataan jumlah hewan berisiko x kurun waktu }}
$$

\section{MATRIKS KATEGORI KASUS}

Kasus dikategorikan berdasarkan nilai incidence rate (IR). Rentang nilai incidence rate diperoleh dari hasil perkurangan nilai IR tertinggi dengan nilai IR terendah, kemudian dibagi 3 sesuai dengan jumlah kategori. Risiko akhir merupakan hasil perpaduan kategori kasus setiap tahunnya selama 3 tahun, menggunakan matriks analisis kualitatif yang dapat dilihat pada Tabel 1.

Tabel 1 Matriks analisis risiko secara kualitatif (diadaptasi dari WHO rapid risk assessment guideline)

\begin{tabular}{lcccc}
\hline Kategori & Negligible & Low & Medium & High \\
\hline Negligible & Negligible & Low & Low & Medium \\
Low & Low & Low & Medium & Medium \\
Medium & Low & Medium & Medium & High \\
High & Medium & Medium & High & High \\
\hline
\end{tabular}

Keterangan: Negligible (IR=0); Low ( $\mathrm{IR}=1$-15); Medium $(\mathrm{IR}=16-30) ;$ High $(\mathrm{IR}=31$-45); IR (incidence rate per 10.000 ekor-tahun)

Rumus menghitung risiko akhir selama 3 tahun adalah sebagai berikut:

$$
\text { Risiko akhir }=\left(\mathrm{Ct}_{1} \times \mathrm{Ct}_{2}\right) \times \mathrm{Ct}_{3}
$$

Keterangan:

$\mathrm{Ct}_{1}$ : Kategori kasus tahun 2015

$\mathrm{Ct}_{2}$ : Kategori kasus tahun 2016

$\mathrm{Ct}_{3}$ : Kategori kasus tahun 2017

\section{HASIL DAN PEMBAHASAN}

\section{KEADAAN PETERNAKAN DAN FASILITAS KESWAN DI BARRU}

Kabupaten Barru memiliki potensi yang baik di bidang peternakan, khususnya jenis komoditi sapi potong. Salah satu aspek penting dalam peternakan adalah manajemen pemeliharaan ternak. Manajemen yang baik dapat meminimalisir kerugian yang diakibatkan oleh turunnya produktifitas, biaya pengobatan, dan risiko kematian ternak (Subronto, 2008). Mayoritas peternakan sapi potong di Kabupaten Barru menerapkan sistem pemeliharaan secara ekstensif. Sapi dilepas di padang pengembalaan dan disediakan tempat bernaung. Sistem pemeliharaan tersebut cukup menyulitkan dalam melakukan desinfeksi areal peternakan dan menajemen kesehatan ternak. Menurut Subronto (2008), manajemen peternakan dan sistem pemeliharaan yang buruk dapat memudahkan masuk dan menyebarnya penyakit ke dalam peternakan.

Dinas Peternakan Kabupaten Barru telah mencatat kejadian penyakit pada ternak, termasuk skabies. Pelaporan kejadian penyakit pada ternak di Barru telah menggunakan sistem iSIKHNAS yang berjalan sejak tahun 2015. iSIKHNAS adalah sistem informasi kesehatan hewan Indonesia yang telah terintegrasi. Sistem ini telah dirancang untuk meningkatkan kualitas dan efisiensi pengumpulan data (iSIKHNAS, 2015). Sistem iSIKHNAS memudahkan peternak dalam melaporkan kejadian penyakit dengan mengirimkan pesan singkat kepada kaderkader yang ditempatkan di setiap wilayah. Sistem tersebut juga memudahkan semua staf yang terkait kesehatan hewan dalam bekerja.

Keberhasilan sektor peternakan tidak lepas dari sumber daya manusia dan fasilitas kesehatan hewan (Sonbait dan Wambrauw, 2019). Sumber daya dan fasilitas tersebut sangat berperan dalam menunjang kesehatan ternak dan mengendalikan penyakit. Kabupaten Barru memiliki 2 unit puskeswan yang terletak di Kecamatan Barru dan 
Kecamatan Tanete Rilau. Pengujian lebih lanjut terhadap penyakit dilakukan di BBVet Maros. Terdapat tenaga medik hewan yang terdiri atas 2 orang dokter hewan, 8 orang paramedik, dan beberapa petugas terlatih yang tersebar di setiap kecamatan. Berdasarkan Peraturan Menteri Pertanian nomor 64 tahun 2007, sumber daya manusia yang bertugas di puskeswan paling kurang terdiri atas 1 orang dokter hewan, 2 orang paramedik veteriner, dan 4 orang teknis puskeswan. Puskeswan mempunyai tugas melakukan kegiatan pelayanan kesehatan hewan di wilayah kerjanya. Hal tersebut telah terpenuhi di Kabupaten Barru, namun dokter hewan dinilai masih kurang jumlahnya mengingat wilayah Kabupaten Barru yang cukup luas.

\section{KASUS SKABIES PADA SAPI POTONG DI BARRU}

Skabies termasuk salah satu penyakit yang penting untuk dikendalikan karena cukup berperan dalam sektor peternakan. Data kasus skabies pada sapi potong di Kabupaten Barru dapat dilihat pada Tabel 2.

Tabel 2. Kasus skabies pada sapi potong di Kabupaten Barru

\begin{tabular}{lcccc}
\hline Kecamatan & \multicolumn{3}{c}{ Jumlah kasus } & Jumlah kasus dalam 3 \\
\cline { 2 - 4 } & Tahun 2015 & Tahun 2016 & Tahun 2017 & $\begin{array}{c}\text { tahun } \\
\text { Pujananting }\end{array} 0^{\text {Tanete Riaja }}$ \\
Tanete Rilau & 8 & 0 & 20 & 85 \\
Barru & 0 & 24 & 53 & 9 \\
Balusu & 7 & 1 & 8 & 40 \\
Soppeng Riaja & 0 & 4 & 29 & 5 \\
Mallusetasi & 5 & 5 & 0 & 16 \\
\hline Jumlah & 40 & 2 & 9 & 95 \\
\hline
\end{tabular}

Jumlah kasus selama 3 tahun (20152017) yaitu sebanyak 270 kasus. Jumlah kasus di setiap kecamatan cenderung meningkat setiap tahunnya. Peningkatan paling signifikan terjadi pada tahun 2016 dengan jumlah 72 kasus menjadi 138 kasus pada tahun 2017. Kecamatan Mallusetasi memiliki jumlah kasus terbanyak dalam kurun waktu 3 tahun dibandingkan 6 kecamatan lainnya. Penentuan kasus positif berdasarkan pada hasil diagnosis setelah dilakukan pemeriksaan.

Diagnosis ditetapkan berdasarkan gejala klinis yang teramati, yaitu bulu rontok dan kulit gatal, serta ditemukannya tungau pada kerokan kulit. Tidak pernah dilakukan pemeriksaan laboratorium lebih lanjut untuk kasus skabies. Menurut Wendel dan Rompalo (2002), penegakan diagnosis skabies dapat dilakukan dengan melihat gejala klinis dan dikonfirmasi dengan pemeriksaan laboratorik. Umumnya, gejala klinis skabies berupa rasa gatal, bintik-bintik merah, papula, dan vesikula. Menurut Walton et al. (2004), cara diagnosis berdasarkan pada gejala klinis dalam prakteknya sulit ditegakkan karena berbagai penyakit kulit lainnya memberikan gambaran klinis yang mirip dengan skabies, sehingga perlu dilakukan kerokan kulit. Diagnosis skabies positif jika ditemukan tungau, nimpa, larva, telur atau kotoran S. scabiei pada hasil kerokan (Robert dan Fawcett, 2003). Strategi lain untuk melakukan diagnosis skabies adalah tes tinta, videodermatoskopi, dan biopsi kulit (Burkhart et al., 2000).

\section{INCIDENCE RATE SKABIES PADA SAPI POTONG DI BARRU}

Insidensi adalah gambaran tentang jumlah kasus baru yang terjadi di dalam suatu populasi selama periode waktu tertentu. Incidence rate adalah tolak ukur dari kecepatan rata-rata penyebaran penyakit (Cameron, 1999). Data insidensi kasus skabies pada sapi potong di Kabupaten Barru setiap tahunnya dapat dilihat pada Tabel 3. 
Tabel 3 Data insidensi kasus skabies per tahun di Kabupaten Barru

\begin{tabular}{lccc}
\hline Tahun & Jumlah kasus & Populasi & Incidence rate (Kasus/10.000 ekor-tahun) \\
\hline 2015 & 60 & 68730 & 9 \\
2016 & 72 & 70816 & 10 \\
2017 & 138 & 72788 & 19 \\
\hline Rataan 3 tahun & 270 & 70778 & 13 \\
\hline
\end{tabular}

Nilai incidence rate kasus skabies pada sapi potong di Kabupaten Barru dalam kurun waktu 3 tahun yaitu 13 kasus per 10000 ekortahun. Peningkatan incidence rate tiap tahunnya dipicu oleh mengingkatnya kepadatan populasi sapi dan mobilitas ternak dari tahun ke tahun, namun kontrol terhadap lalu lintas ternak masih rendah, sehingga skabies lebih mudah menyebar dan seringkali terjadi infeksi ulang.

Dinas Peternakan Kabupaten Barru menambahkan bahwa ternak sapi yang positif terkena skabies tidak diisolasi ke tempat khusus. Menurut Kementerian Pertanian (2014), pola peternakan tradisional dan manajemen pemelihaaan secara ekstensif dapat menyulitkan dalam pengawasan lalu lintas ternak. Selain itu, hewan yang sakit tidak diisolasi dari hewan yang sehat dapat menyebabkan penyebaran penyakit yang lebih luas. Kejadian skabies menyebar di seluruh kecamatan. Tiap kecamatan memiliki nilai incidence rate yang berbeda-beda. Data insidensi kasus skabies pada sapi potong di Kabupaten Barru pada setiap kecamatan dapat dilihat pada Tabel 4.

Tabel 4 Data insidensi kasus skabies per kecamatan di Kabupaten Barru

\begin{tabular}{|c|c|c|c|c|}
\hline Kecamatan & $\begin{array}{c}\text { Jumlah kasus } \\
\text { (3 tahun) }\end{array}$ & Populasi & $\begin{array}{c}\text { Densitas } \\
(\text { ekor/km²) }\end{array}$ & $\begin{array}{l}\text { Incidence rate (Kasus/ } \\
10000 \text { ekor-tahun) }\end{array}$ \\
\hline Pujananting & 20 & 10572.67 & 33.64 & 6 \\
\hline Tanete Riaja & 85 & 12676.50 & 72.73 & 22 \\
\hline Tanete Rilau & 9 & 9869.17 & 124.66 & 3 \\
\hline Barru & 40 & 13374.00 & 67.10 & 10 \\
\hline Balusu & 5 & 6344.50 & 56.55 & 3 \\
\hline Soppeng Riaja & 16 & 8791.33 & 111.42 & 6 \\
\hline Mallusetasi & 95 & 9149.83 & 42.25 & 35 \\
\hline
\end{tabular}

Kecamatan Mallusetasi memiliki nilai incidence rate tertinggi, yaitu 35 kasus per 10 000 ekor-tahun, diikuti dengan Kecamatan Tanete Riaja 22 kasus per 10000 ekor-tahun. Kecamatan Ballusu dan Tanete Rilau memiliki nilai incidence rate terendah, yaitu 3 kasus per 10000 ekor-tahun. Tingginya incidence rate di Kecamatan Mallusetasi karena berbatasan langsung dengan kota Pare-pare, sehingga lalu lintas ternak antar wilayah cukup tinggi. Lalu lintas ternak dari satu tempat ke tempat lainnya menjadi pintu masuknya bibit skabies ke suatu daerah sehingga harus diperhatikan secara serius (Wardhana et al., 2006).

Faktor lain yang mempengaruhi tingginya kasus skabies adalah densitas ternak. Peternakan yang terlalu padat akan rnemberi peluang baik bagi peningkatan populasi tungau (Wardhana et al., 2006). Faktor densitas tersebut tidah berpengaruh untuk kasus skabies di Kabupaten Barru, terlihat bahwa Kecamatan Tanete Rilau memilki densitas yang tinggi, namun memiliki incidence rate yang rendah. Penyebaran penyakit dapat dicegah dengan melakukan kontrol dan pengendalian penyakit pada ternak (Yusdja dan Winarso, 2009).

Serangkaian tindakan pencegahan, pengobatan, dan pengendalian terhadap skabies pada sapi potong telah dilakukan oleh Dinas Peternakan di Kabupaten Baru. Areal peternakan yang luas menyebabkan sulitnya dilakukan desinfeksi. Menurut Wardhana et al. (2006), menjaga kebersihan kandang dan lingkungannya dapat mencegah dan 
mengendalikan skabies. Sapi yang positif skabies hanya diobati dengan injeksi ivermectin dan pemberian obat herbal untuk mengurangi rasa gatal. Biaya untuk pengobatan tersebut ditanggung sendiri oleh peternak. Dinas tidak pernah melakukan program pengobatan khusus seperti dipping dan spraying pada ternak. Menurut Tarigan (2007), penanggulangan skabies yang efektif dilakukan dengan cara mengobati individu yang secara klinis terlihat menderita skabies menggunakan skabisida topikal yang dioleskan pada daerah yang sakit, atau bisa juga dilakukan dengan cara dipping (perendaman), brushing (disikat), spraying (penyemprotan), oral, dan parenteral (injeksi ivermectin).

Pengawasan lalu lintas ternak yang masuk ke suatu wilayah termasuk tindakan yang penting dalam pengendalian (Kementrian Pertanian, 2014). Tindakan yang telah dilakukan oleh pihak dinas yaitu dengan menyediakan fasilitas check point di setiap pintu masuk Kabupaten Barru sebagai tempat melalukan pemeriksaan fisik awal. Selain itu, setiap ternak baru sudah disertai dengan surat keterangan kesehatan hewan (SKKH). Tindakan lain yang dilakukan oleh dinas yaitu sosialisasi skabies, namun sosialisasi tersebut belum sempat dilakukan di seluruh kecamatan. Suhardono et al. (2005) membuktikan bahwa pengobatan skabies yang dilakukan pasca penyuluhan kepada peternak menunjukkan hasil yang nyata dibandingkan tanpa penyuluhan.

RISIKO PENYEBARAN SKABIES PADA SAPI POTONG DI BARRU

Kejadian penyakit di setiap kecamatan dikategorikan berdasarkan nilai incidence rate. Kategori kasus dan risiko akhir dapat dilihat pada Tabel 5.

Tabel 5 Kategori kasus skabies pada sapi potong di Kabupaten Barru

\begin{tabular}{|c|c|c|c|c|c|c|c|}
\hline \multirow{2}{*}{ Kecamatan } & \multicolumn{2}{|c|}{2015} & \multicolumn{2}{|c|}{2016} & \multicolumn{2}{|c|}{2017} & \multirow{2}{*}{ Risiko } \\
\hline & IR & $\mathrm{Ct}_{1}$ & IR & $\mathrm{Ct}_{2}$ & IR & $\mathbf{C t}_{3}$ & \\
\hline Pujananting & 0 & $\mathrm{~N}$ & 0 & $\mathrm{~N}$ & 19 & $\mathrm{M}$ & Low risk \\
\hline Tanete Riaja & 7 & $\mathrm{~L}$ & 19 & M & 41 & $\mathrm{H}$ & High risk \\
\hline Tanete Rilau & 0 & $\mathrm{~N}$ & 1 & $\mathrm{~L}$ & 8 & $\mathrm{~L}$ & Low risk \\
\hline Barru & 5 & $\mathrm{~L}$ & 3 & $\mathrm{~L}$ & 21 & $\mathrm{M}$ & Medium risk \\
\hline Balusu & 0 & $\mathrm{~N}$ & 8 & $\mathrm{~L}$ & 0 & $\mathrm{~N}$ & Low risk \\
\hline Soppeng Riaja & 6 & $\mathrm{~L}$ & 2 & $\mathrm{~L}$ & 9 & $\mathrm{~L}$ & Low risk \\
\hline Mallusetasi & 45 & $\mathrm{H}$ & 39 & $\mathrm{H}$ & 20 & M & High risk \\
\hline
\end{tabular}

Keterangan : IR (Incidence rate per 10000 ekor-tahun), Ct (Kategori), N (Negligible), L (Low), $\mathrm{M}$ (Medium), $\mathrm{H}$ (High).

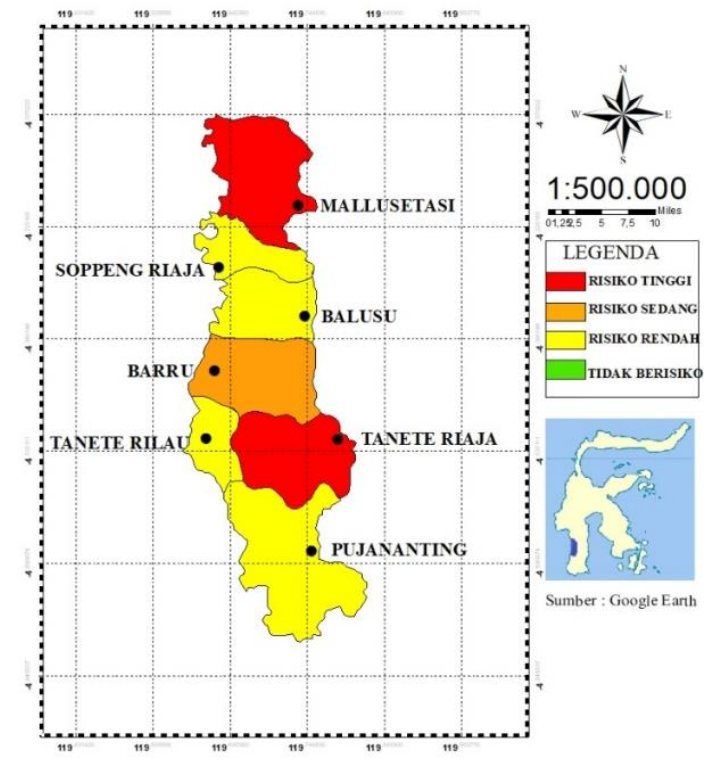

Gambar 1. Peta risiko penyebaran skabies pada sapi potong di Kabupaten Barru 
Setiap kecamatan memiliki incidence rate yang berbeda pada setiap tahunnya. Nilai incidence rate tersebut kemudian dikategorikan dan dipadukan menggunakan rumus untuk mendapat risiko akhir. Risiko akhir digolongkan menjadi 3, yaitu low risk, medium risk, dan high risk. Setelah diketahui tingkat risiko di setiap kecamatan, kemudian dapat dilihat penyebarannya. Peta risiko penyebaran kasus skabies pada sapi potong di Kabupaten Barru dapat dilihat pada Gambar 1.

Terdapat 2 kecamatan yang termasuk ke wilayah dengan risiko tinggi (high risk), yaitu Kecamatan Mallusetasi dan Kecamatan Tanete Riaja. Terdapat 1 kecamatan yang termasuk ke wilayah dengan risiko sedang (medium risk), yaitu Kecamatan Barru. Kecamatan lainnya termasuk ke wilayah dengan risiko rendah (low risk), yaitu Kecamatan Pujananting, Kecamatan Tanete Rilau, Kecamatan Ballusu, dan Kecamatan Soppeng Riaja. Lalu lintas ternak sangat berpengaruh terhadap penyebaran penyakit (Wardhana et al., 2006). Pengendalian lalu lintas dilakukan dengan mengawasi penggembalaan ternak atau pergerakan hewan yang keluar dari daerah berisiko tinggi di sepanjang tahun. Peningkatan surveilans dan kontrol perbatasan harus segera dilaksanakan terutama pada wilayah berisiko tinggi (iSIKHNAS, 2015). Kecamatan Mallusetasi dan Kecamatan Tanete Riaja perlu digiatkan dan diprioritaskan tindakan pengendaliannya karena termasuk ke wilayah risiko tinggi.

\section{KESIMPULAN}

Kasus skabies pada sapi potong di Kabupaten Barru menyebar di seluruh kecamatan. Kecepatan penyebaran ditunjukkan dengan nilai incidence rate sebesar 13 kasus per 10000 ekor-tahun. Nilai incidence rate tersebut selalu meningkat setiap tahunnya. Tindakan pengendalian yang selama ini dilakukan belum berhasil mengurangi kecepatan penyebaran. Kejadian penyakit paling tinggi terjadi di kecamatan Mallusetasi dengan incidence rate sebesar 35 kasus per 10000 ekor-tahun. Terdapat 2 wilayah yang tergolong ke dalam risiko tinggi, yaitu Kecamatan Mallusetasi dan Kecamatan Tanete Riaja.

\section{UCAPAN TERIMA KASIH}

Penulis mengucapkan terima kasih kepada pimpinan dan petugas Dinas Peternakan Kabupaten Barru yang telah banyak membantu selama proses pengumpulan data.

\section{DAFTAR PUSTAKA}

Burkhart C. G., Burkhart C. M., Burkhart K.M. 2000. An epidemiologic and therapeutic reassessment of scabies. Cutis. 65(4):233240.

Cameron A. 1999. Survey Toolbox for Livestock Diseases-A Practical Manual and Software Package for Active Surveillance in Developing Countries. Australia: ACIAR.

Direktorat Jendral Peternakan dan Kesehatan Hewan. 2014. Pedoman Umum Program Swasembada Daging Sapi. Jakarta (ID): Ditjennak.

Food Agricultural Organization. 2010. The State of Food and Agriculture. Rome (IT): Food Agricultural Organization.

Kementerian Pertanian. 2014. Manual Penyakit Hewan Mamalia. Cetakan kedua. Jakarta (ID): Direktorat Jendral Peterakan dan Kesehatan Hewan.

Nazir M. 2003. Metode Penelitian. Jakarta (ID): Ghalia Indonesia.

Putra A. A. G. 1994. Kajian epidemiologi dan kerugian ekonomi scabies. Laporan Koordinasi Kesehatan Hewan Wilayah Nusa Tenggara tanggal 16-18 Nopember 1994. Denpasar (ID): Balai Penyidikan Penyakit Hewan Wilayah VI.

Robert S, and Fawcett MD. 2003. Ivermectin use in scabies. Journal of American Family Physician. 68(6):1089-1092.

Sistem Informasi Kesehatan Hewan Nasional ter-integrasi. 2015. Apa itu iSIKHNAS? [Internet]. [diunduh 2019 Mar 22]. Tersedia pada: http://wiki.isikhnas.com.

Sistem Informasi Kesehatan Hewan Nasional ter-integrasi. 2015. Program Pengendalian dan Pembarantasan Penyakit [Internet]. [diunduh 2019 Mar 10]. Tersedia pada: http://wiki.isikhnas.com/Advanced_Field Epi:

Manual_Disease_Control_and_Eradicatio n_Programs/id 
Subronto. 2008. Ilmu Penyakit Ternak. Yogyakarta (ID): UGM Pr.

Suhardono J. Manurung A.P., Batubara, Wasito dan Harahap. 2005. Pengendalian penyakit kudis pada kambing di Kabupaten Deli Serdang. Prosiding Seminar Nasional Teknologi Peternakan dan Veteriner. [2005 Sept 12]. Bogor (ID): Puslitbang Peternakan.

Tarigan S. 2007. Vaksin Skabies Dibutuhkan Namun Sulit Diwujudkan. Bogor (ID): Balai Besar Veteriner.

Walton S. F., Myerscough and Currie B.J., 2004. Studies in vitro on the relative efficacy of current acaricides for Sarcoptes scabiei var hominis. Tranactions of the Royal Society of Tropical Medicine and Hygiene. 94(1): 92-96.
Wardhana A.H., Manurung J. Dan Iskandar T. 2006. Skabies: Tantangan penyakit zoonosis masa kini dan masa datang. Wartazoa. 16(1):40-52.

Wendel J. dan Rompalo A. 2002. Scabies and pediculosis pubis: an update of treatment regimens and general review. Clinical Infectious Diseases. 35(2):146-151.

World Health Organization. 2014. Scabies: Neglected Top Dis 2013 [Internet]. [diunduh 2019 Mar 3]. Tersedia pada: http://www.who.int/ neglected_ diseases/ diseases/scabies/en/.

Yusdja Y. dan Winarso B. 2009. Kebijakan pembangunan sosial ekonomi menuju sistem peternakan yang diharapkan. Analisis Kebijakan Pertanian. 7(3): 269282. 